\title{
PENINGKATAN KUALITAS WARNA KUNING DAN MERAH SERTA PERTUMBUHAN BENIH IKAN KOI MELALUI PENGAYAAN TEPUNG KEPALA UDANG DALAM PAKAN
}

\author{
I Wayan Subamia, Nina Meilisza, dan Asep Permana \\ Balai Penelitian dan Pengembangan Budidaya Ikan Hias \\ Jl. Perikanan No. 13, Pancoran Mas, Depok 16436 \\ E-mail: sirunina@yahoo.com
}

(Naskah diterima: 7 Januari 2013; Disetujui publikasi: 10 Oktober 2013)

\begin{abstract}
ABSTRAK
Ikan hias koi merupakan salah satu produk perikanan yang budidayanya telah dikuasai oleh petani ikan di beberapa daerah. Tujuan utama penelitian ini adalah untuk meningkatkan kualitas warna benih ikan hias koi melalui pengayaan tepung kepala udang dalam pakan. Penelitian dilakukan dengan menggunakan Rancangan Acak Lengkap (RAL) dengan perlakuan dosis tepung kepala udang dalam formulasi pakan sebagai sumber karotenoid yaitu: $0 \%$ (kontrol), 5\% 10\% 15\% Pakan yang diberikan diformulasikan dengan isoprotein (30\%), dan isolipid (15\%). Ikan yang digunakan adalah benih dan ditempatkan dalam hapa- hapa di kolam. Pengamatan yang dilakukan selama pemeliharaan adalah parameter kualitas warna yang dilakukan secara kualitatif dengan menggunakan TCF (Toca Color Finder), sedangkan pengukuran kuantitatifnya dilakukan dengan pengukuran total karotenoid pakan dan jaringan tubuh ikan. Selain itu, dilakukan pula pengamatan parameter pertumbuhan panjang, dan bobot yang dihasilkan. Hasil penelitian menunjukkan bahwa peningkatan kualitas warna pada ikan koi optimal pada pemberian tepung kepala udang sebesar $10 \%$ dicirikan dari nilai warna kuning dan merah. Selama penelitian juga diketahui bahwa tidak ada perbedaan yang signifikan terhadap pertumbuhan bobot dan panjang mutlak, laju pertumbuhan spesifik bobot dan panjang tubuh, dan sintasan pada semua perlakuan.
\end{abstract}

KATA KUNCl: kualitas, benih, pakan, koi (Cyprinus carpio)

ABSTRACT: The quality improvement on red and yellow colour performances to juveniles of koi carp through feed improvement. By: I Wayan Subamia, Nina Meilisza, and Asep Permana

The koi carp is the aquaculture fisheries product which have be managed by fish farmers in the several locality. This aim research is improving the colour quality juveniles of koi carp through shrimp head meal in. Randomized complete design in triplicates done with dosages of shrimp head meal in feed as carotenoid source namely $0 \%$ (control), $5 \%, 10 \%$ and $15 \%$ in feed. Fish fed the artificial feed formulated by isoprotein (30\%), and isolipid (15\%). Juveniles stocked in nets at ponds. The observation done during research with the parameters of colour quality also conducted in qualitative data used TCF (Toca Color Finder), whereas the quantitative data measured by the total carotenoid measurements on feed and tissues of fish body. Parameter of weight and length also observed. Results showed that $10 \%$ dosage of shrimp head meal in feed was the optimal colour improvement on koi carp. During research also shows that no significant different on growth of weight, length and survival rate on all of treatments.

KEYWORDS: quality, juveniles, feed, koi carp 


\section{PENDAHULUAN}

Ikan koi merupakan jenis ikan hias dari sekian banyak ikan hias yang sudah mampu dimasyarakatkan dan dikuasai teknologi budidayanya oleh masyarakat. Ikan hias koi sudah lama dikenal masyarakat karena bentuk yang bermacam- macam dan warnanya yang indah sehingga permintaan akan ikan hias ini semakin meningkat. Kualitas ikan hias akan menentukan nilai ekonomis dan estetiknya, tampilan warna yang indah merupakan salah satu indikator yang menjadi daya tarik. Warna pada ikan disebabkan oleh adanya sel pigmen atau chromatophore yang terdapat dalam dermis pada sisik, di luar maupun di bawah sisik.

Warna merah atau kuning merupakan warna yang banyak mendominasi ikan hias. Komponen utama pembentuk pigmen merah dan kuning ini adalah pigmen karotenoid. Pada ikan, karotenoid tidak dapat disintesis secara de novo (Goodwin, 1984; Kalinowski et al., 2007). Penambahan sumber peningkat warna dalam pakan ikan akan mengakibatkan adanya peningkatan pigmen warna pada tubuh ikan tersebut, minimal ikan mampu mempertahankan pigmen warna pada tubuhnya selama masa pemeliharaan. Keberadaan astaksantin adalah yang terbesar dan terserap pada hewanhewan air seperti udang- udangan, krill, trout, atau salmon.

Tepung kepala udang merupakan salah satu jenis sumber karoten yang berasal dari hasil pengolahan limbah tubuh udang yang sudah tidak dimanfaatkan dan mengandung bahan- bahan seperti mineral, protein, khitin, dan karotenoid (Damuningrum, 2002). Bagian udang yang dimanfaatkan pada produk beku hanya berkisar 20-30\% yang berupa daging utuh, sedangkan kulit, kepala dan kotoran lainnya dianggap sebagai limbah. Tingginya limbah dari industri udang beku ini perlu ditangani sebaik mungkin untuk mencegah timbulnya pencemaran lingkungan. Pemanfaatan limbah udang merupakan salah satu alternatif yang dapat meningkatkan nilai guna dan nilai ekonomisnya. Perkembangan lebih lanjut menunjukkan bahwa dari limbah udang dapat diproduksi khitin, khitosan, protein konsentrat, flavoran (zat perasa) dan pigmen karotenoid (Desiana, 2000).

Seiring dengan perkembangan teknologi pembuatan pakan ikan, sumber- sumber karotenoid dapat diformulasikan dan dimasukkan ke dalam pakan. Selain itu kelengkapan dan keseimbangan nutrien pakan buatan (protein, lemak, karbohidrat, vitamin, dan mineral) untuk ikan yang dipelihara lebih mudah diatur dan diketahui sesuai kebutuhan dengan ikan. Penggunaan tepung kepala udang yang ditambahkan ke dalam pakan buatan sebagai sumber karotenoid alami, diharapkan dapat memberi nilai lebih dari sisi kualitas dan dapat meminimasi biaya produksi karena dianggap ramah lingkungan, mendaur ulang limbah, dan masih mengandung nutrisi yang tinggi (protein $\pm 49 \%$ lipid $\pm 5 \%$ berat kering) (Sachindra $\&$ Mahendrakar, 2005; Sánchez-Camargo et al., 2011).

Diketahui bahwa kadar protein yang baik bagi pertumbuhan benih ikan koi, maskoki, dan beberapa jenis Cyprinid lainnya berkisar antara 29-43\% (Lochmann \& Phillips, 1994; Yanong, 1996; Min Xue \& Yibo Cui, 2001; Sales \&Janssens, 2003; Bandyopadhyay et al., 2005) maka penggunaan kadar protein sebesar $30 \%$ dalam penelitian ini dinilai lebih efisien. Selain itu, untuk mendapatkan hasil yang baik dalam penelitian ini, kadar lipid juga dipertimbangkan. Kadar lipid merupakan salah satu faktor yang mempengaruhi penyerapan karotenoid dalam tubuh ikan, kadar lipid yang optimal sekitar $15 \%$ untuk menghasilkan penyerapan canthaxantin yang tinggi seperti pada kasus ikan rainbow trout (Tonissen et al., 1990).

Berdasarkan hal tersebut, perlu dilakukan penelitian untuk mengetahui pengaruh pemberian pakan yang mengandung kepala udang dengan konsentrasi berbeda terhadap performansi warna, dan pertumbuhan ikan koi.

\section{BAHAN DAN METODE}

Kegiatan ini dilaksanakan di Balai Penelitian dan Pengembangan Budidaya Ikan Hias (BPPBIH), Depok dengan menggunakan jenis ikan hias koi (Cyprinus sp.). Penelitian dilakukan dengan menggunakan Rancangan Acak Lengkap (RAL) dengan perlakuan dosis tepung kepala udang dalam formulasi pakan sebagai sumber karotenoid yaitu: $0 \%($ kontrol), $5 \%$ 10\% dan $15 \%$ Jenis ikan yang digunakan adalah benih ikan koi dan ditempatkan dalam hapa- hapa di kolam. Benih yang digunakan berukuran bobot $\pm 30,5 \mathrm{~g}$; dan panjang \pm 10 $\mathrm{cm}$ per individu dengan padat tebar sebanyak sepuluh ekor per hapa.

Pakan yang diberikan adalah pakan buatan yang diformulasikan dengan isoprotein $(30 \%$, isolipid ( $15 \%$, dan isoenergi $(20 \mathrm{MJ} / \mathrm{kg}$ ) (Tabel 
tubuh, laju pertumbuhan spesifik panjang, dan sintasan pada benih ikan koi seperti tertera pada Tabel 2.

Hasil penelitian pada ikan koi dalam Tabel 2 menunjukkan bahwa semua parameter pertumbuhan bobot (mutlak, laju pertumbuhan spesifik), pertumbuhan panjang (mutlak, laju pertumbuhan spesifik panjang), dan sintasan tidak memperlihatkan perbedaan yang nyata $(P>0,05)$. Gambaran pertambahan bobot individu rata- rata selama penelitian memperlihatkan adanya pertumbuhan dan berlangsung naik selama penelitian. Pertambahan bobot memperlihatkan bahwa pada masing- masing perlakuan pergerakan bobot relatif sama dan berhimpit satu sama lain meskipun garis tertinggi dicapai pada perlakuan tepung kepala udang dalam pakan 10\%namun jika dibandingkan dengan perlakuan lain cenderung tidak signifikan (Gambar 1).

Hal yang sama juga ditunjukkan pada gambaran pertambahan panjang individu ratarata selama penelitian yang memperlihatkan adanya pertumbuhan dan naik selama penelitian. Pertambahan panjang memperlihatkan bahwa pada masing- masing perlakuan laju pergerakan panjang relatif sama dan berhimpit satu sama lain meskipun garis tertinggi dicapai pada perlakuan tepung kepala udang dalam pakan $10 \%$ namun jika dibandingkan dengan perlakuan lain cenderung juga tidak signifikan (Gambar 2).

Pemberian pakan buatan yang diperkaya dengan tepung kepala udang dalam pakan telah menghasilkan pertumbuhan baik bobot maupun panjang di semua perlakuan pada ikan koi. Hal ini membuktikan bahwa ikan ini mampu memanfaatkan pakan yang diberikan untuk pemeliharaan tubuh maupun pertumbuhan. Pakan dalam penelitian ini dianggap telah memenuhi semua kebutuhan gizi ikan, hal ini terlihat dari nilai nutrisi yang terkandung dalam pakan dan performansi yang dihasilkannya. Seperti pernyataan Yandes et al. (2003) bahwa pertumbuhan terjadi apabila ada kelebihan energi setelah energi yang tersedia digunakan untuk metabolisme standar, pencernaan, serta untuk beraktivitas.

Penambahan tepung kepala udang diperkirakan ikut memberikan kontribusi dalam menyumbang nilai nutrisi pakan. Tepung kepala udang adalah limbah udang memiliki banyak komponen yaitu: bahan mineral, khitin, protein, dan pigmen karotenoid. Komponenkomponen tersebut dapat mempunyai nilai ekonomi yang cukup tinggi apabila di-

Tabel 2. Parameter pertumbuhan bobot, panjang, dan sintasan benih ikan koi selama penelitian Table2. The parameters of weight, length, and survival rate on the juveniles of koi carp fish during research

\begin{tabular}{|c|c|c|c|c|}
\hline \multirow{2}{*}{$\begin{array}{l}\text { Parameter } \\
\text { Parameters }\end{array}$} & \multicolumn{4}{|c|}{ Perlakuan (Treatments) } \\
\hline & $\begin{array}{l}\text { A (TKU 0\%) } \\
\text { A (SHM 0\%) }\end{array}$ & $\begin{array}{c}\text { B (TKU 5\%) } \\
\text { B (SHM 5\%) }\end{array}$ & $\begin{array}{l}\text { C (TKU 10\%) } \\
\text { C (SHM 10\%) }\end{array}$ & $\begin{array}{l}\text { D (TKU 15\%) } \\
\text { D (SHM 15\%) }\end{array}$ \\
\hline $\begin{array}{l}\text { Pertambahan bobot mutlak } \\
\text { Weight gain }(\mathrm{g})\end{array}$ & $14.25 \pm 3.40^{\mathrm{a}}$ & $15.07 \pm 5.88^{a}$ & $15.23 \pm 1.92^{\mathrm{a}}$ & $11.18 \pm 1.43^{a}$ \\
\hline $\begin{array}{l}\text { Pertambahan panjang mutlak } \\
\text { Length gain }(\mathrm{cm})\end{array}$ & $1.49 \pm 0.54^{\mathrm{a}}$ & $1.53 \pm 0.40^{\mathrm{a}}$ & $1.19 \pm 0.41^{\mathrm{a}}$ & $1.4 \pm 0.17^{a}$ \\
\hline $\begin{array}{l}\text { Laju pertumbuhan spesifik bobot } \\
\text { Spesific growth rate of weight }(\%)\end{array}$ & $0.80 \pm 0.19^{a}$ & $0.84 \pm 0.21^{a}$ & $0.79 \pm 0.08^{a}$ & $0.65 \pm 0.08^{a}$ \\
\hline $\begin{array}{l}\text { Laju pertumbuhan spesifik panjang } \\
\text { Spesific growth rate of length }(\%)\end{array}$ & $0.28 \pm 0.10^{a}$ & $0.30 \pm 0.07^{a}$ & $0.22 \pm 0.07^{a}$ & $0.27 \pm 0.04^{a}$ \\
\hline Sintasan (Survival rate) $(\%$ & $100 \pm 0.00^{a}$ & $100 \pm 0.00^{a}$ & $100 \pm 0.00^{\mathrm{a}}$ & $100 \pm 0.00^{a}$ \\
\hline
\end{tabular}

Keterangan (Note):

TKU = Tepung kepala udang; SHM = Shrimp head meal

Angka yang diikuti huruf superscript yang sama pada baris yang sama menunjukkan nilai yang tidak berbeda nyata $(P>0,05)$ (The values under the same superscript in the same row indicate no significant difference $(P>0.05))$ 


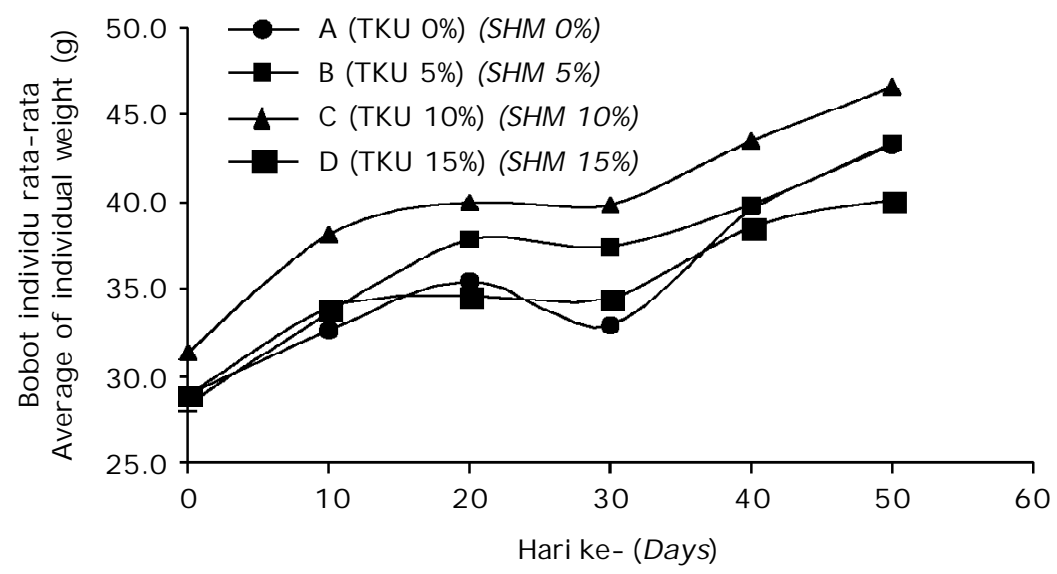

Gambar 1. Bobot individu rata- rata benih ikan koi selama penelitian

Figure 1. The average of individual weight of koi carp fish during research period

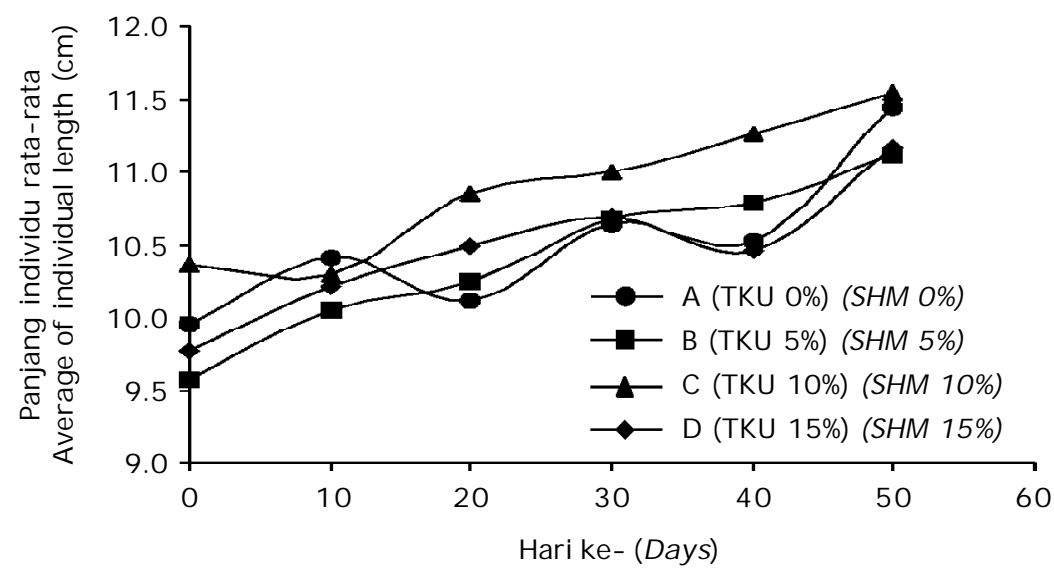

Gambar 2. Panjang total rata- rata individu benih ikan koi selama penelitian

Figure 2. The average of individual total length of koi carp fish during research period

manfaatkan sebaik mungkin (Karmas, 1982). Komponen- komponen yang terdapat dalam kulit udang adalah total $\mathrm{N}$ kasar non protein 4,3\% lemak 0,5\% protein kasar $26,8 \%$ khitin nitrogen 2,4\% khitin 34,9\% abu 29,3\% pospor $0,8 \%$ kalium 8,2\% kalsium 1,7\% (Benjakul \& Sopharodora, 1993). Menurut Shahidi \& Synowicki (1992), limbah udang mengandung protein $41,9 \%$ khitin $17,0 \%$ abu $29,2 \%$ dan lemak 4,5\%dari bahan kering. Hal ini memberikan informasi bahwa penambahan tepung kepala udang dalam pakan selain sebagai sumber karotenoid juga memberikan nilai nutrisi sebagai bahan baku alternatif pakan.
Selain pertumbuhan, kualitas ikan hias juga dinilai berdasarkan warna yang ditampilkannya. Berbagai warna- warni indah pada ikan dalam hal ini ikan koi pada dasarnya dihasilkan oleh sel- sel pigmen (kromatofor) yang terletak pada lapisan dermis. Sel- sel tersebut masing- masing mempunyai nama sesuai dengan jenis- jenis pigmen yang dikandungnya, yaitu: melanofor yang menyimpan pigmen hitam, eritrofor menyimpan pigmen merah, xantofor menyimpan pigmen kuning, dan iridofor yang tidak mengandung pigmen tetapi mengandung kristal- kristal guanin yang mampu memantulkan atau memendarkan cahaya ke dalam 
komponen warna penyusunnya (Anonim, 2002).

Sel- sel penyandang pigmen ini berbentuk menyerupai bintang. Perubahan warna yang terjadi pada ikan dipengaruhi oleh persebaran granula pigmen dalam sel tersebut. Menurut Sally (1997), pergerakan granula pigmen pada kromatofor dapat dibedakan menjadi dua tipe, yaitu kromatofor dengan granula pigmen yang berkumpul di dekat nukleus dan kromatofor yang tersebar di seluruh bagian sel. Granula pigmen yang tersebar di dalam sel menyebabkan sel tersebut dapat menyerap sinar dengan sempurna sehingga terjadi peningkatan warna sisik, sedangkan granula pigmen yang berkumpul dalam sel menyebabkan penurunan warna sisik.

Hasil kuantifikasi visual menggunakan TCF (Toca Colour Finder) diketahui bahwa warna merah pada ikan koi terlebih dahulu ditampilkan dalam warna kuning kemerahan selanjutnya mengarah ke warna merah. Hasil kuantifikasi ini telah menampilkan empat perankingan warna dimulai dari warna terendah menuju tinggi yaitu ranking 1 (kuning kemerahan), 2 (merah pudar), 3 (merah sedang), 4 (merah). Gambar 3 menunjukkan bahwa warna kuning merah pada ikan koi meningkat dibandingkan awal penelitian pada semua perlakuan. Ranking tertinggi (warna merah) dicapai oleh ketiga perlakuan mulai dari perlakuan tepung kepala udang $5 \%$ hingga $15 \%$ dalam pakan pada akhir penelitian. Pakan dengan persentase $0 \%$ tepung kepala udang dalam pakan menghasilkan performansi warna terendah.

Pada ikan koi warna kuning merah mengalami peningkatan dibandingkan kondisi awal penelitian. Hasil ini menunjukkan bahwa ada pengaruh pemberian sumber karotenoid tepung kepala udang dalam pakan terhadap warna ikan koi. Karotenoid yang terdapat dalam tepung kepala udang mempunyai sifat sebagai provitamin A dan dapat berfungsi sebagai antikanker (antioksidan) (Iwasaki \& Murakoshi, 1992). Karotenoid yang bersifat provitamin A dalam pencernaan akan larut dalam lemak. Di lambung proses pencernan lemak tidak begitu efektif. Proses pencernaan lemak secara intensif dimulai pada segmen usus. Dengan demikian penggunaan sumber karotenoid tepung kepala udang dalam penelitian diharapkan juga memberikan nilai tambah bagi kesehatan ikan.

Penyerapan karotenoid dalam sel-sel jaringan ini akan mempengaruhi sel-sel pigmen (kromatofora) dalam kulit ikan. Kandungan astaksantin dalam karotenoid akan meningkatkan pigmen merah pada sel pigmen merah (eritrofora), sehingga warna yang dihasilkan akan tampak lebih jelas. Menurut Vevers (1982), karotenoid pada hewan berperan dalam pemberian warna kuning, jingga dan merah, namun bila berikatan dengan protein akan menjadi karotenoprotein, yang menghasilkan warna biru dan ungu. Karotenoid tersebut diidentifikasi sebagai astaksantin dan canthaksantin.

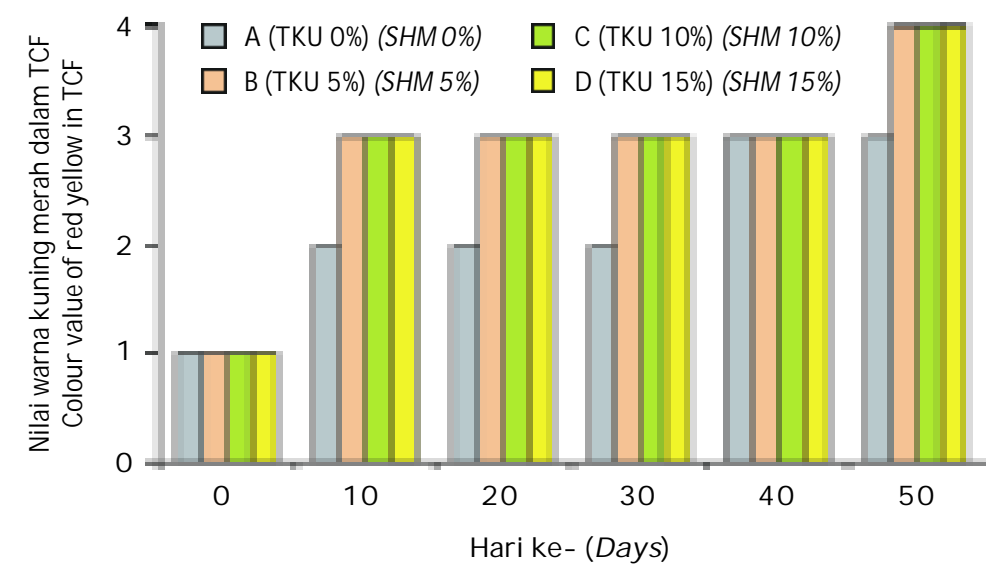

Gambar 3. Nilai warna kuning merah dalam kuantifikasi visual selama penelitian

Figure 3. Colour value of red yellow in visual quantification during research period 
Menurut Evans (1993), pergerakan granula pigmen mengakibatkan perubahan warna disebabkan oleh suhu, cahaya dan lain- lain yang dikendalikan oleh sistem saraf dan hormon. Beberapa penelitian banyak menggunakan sumber-sumber karotenoid untuk meningkatkan warna pada ikan. Karotenoid merupakan suatu kelompok pigmen yang berwarna kuning, orange, atau merah orange, mempunyai sifat larut dalam lemak atau pelarut organik, tetapi tidak larut dalam air (Anonim, 2009). Selain itu Latscha (1991), karotenoid adalah kelompok karoten yang berupa xantofil dan terdiri dari gugus karbon, hidrogen dan oksigen, contohnya taraxanthin, lutein, dan astaksantin. Sedangkan pada perkembangan seksualnya ikan jantan dewasa akan menyimpan karotenoid pada kulit tubuhnya (Bjerkeng et al., 1992).

Untuk menghasilkan data yang objektif, selain menggunakan kuantifikasi visual dengan TCF, warna ikan juga diukur secara spektrometri dengan panjang gelombang tertentu. Nilai pengukuran warna pada al at ini adalah nilai total karotenoid yang terdapat dalam tubuh ikan. Nilai karotenoid ikan menunjukkan perbedaan satu sama lain di mana nilai karotenoid akan semakin besar seiring dengan peningkatan persentase tepung kepala udang dalam pakan (Gambar 4). Hal ini menunjukkan bahwa ada pengaruh yang cukup signifikan terhadap warna ikan koi yang diberikan berbagai perlakuan dosis kepala udang dalam pakan.

Penyimpanan karotenoid dalam tubuh ikan koi dalam penelitian ini telah ditampilkan di bagian kulit di mana warna akan meningkat. Guillaume et al. (2001) menyatakan bahwa karotenoid adalah pigmen yang larut dalam lemak yang memiliki kisaran warna dari kuning hingga merah tua. Karotenoid hanya dapat dideposisikan pada jaringan spesifik (kulit, otot, eksoskeleton, dan kelenjar pencernaan). Jenis karotenoid yang dapat diserap oleh ikan adalah astaksantin dan dapat dikonversi dari canthaxanthin yang sumbernya banyak terdapat pada sebagian besar krustase (udangudangan).

Astaksantin adalah karoten yang paling banyak digunakan dan diaplikasikan (Johnson, 1991). Astaksantin (3,3'-dihydroxy- $\beta, \beta$ kar otena-4,4-dione) merupakan pigmen merah orange pada alga, mikroorganisme dan krustase. Pigmen ini digunakan sebagai makanan tambahan untuk pigmentasi hewan-hewan, seperti ikan salem, udang, dan hewan- hewan yang tak bisa mensintesa $\beta$-karoten sendiri (Storebakken, 1992). Astaksantin warna dasarnya adalah merah, yang akan diserap dan disimpan sebagai pigmen merah, sehingga bila terjadi perubahan pigmen dalam tubuh ikan dapat terlihat pigmentasi warna pada ikan (Latscha, 1990).

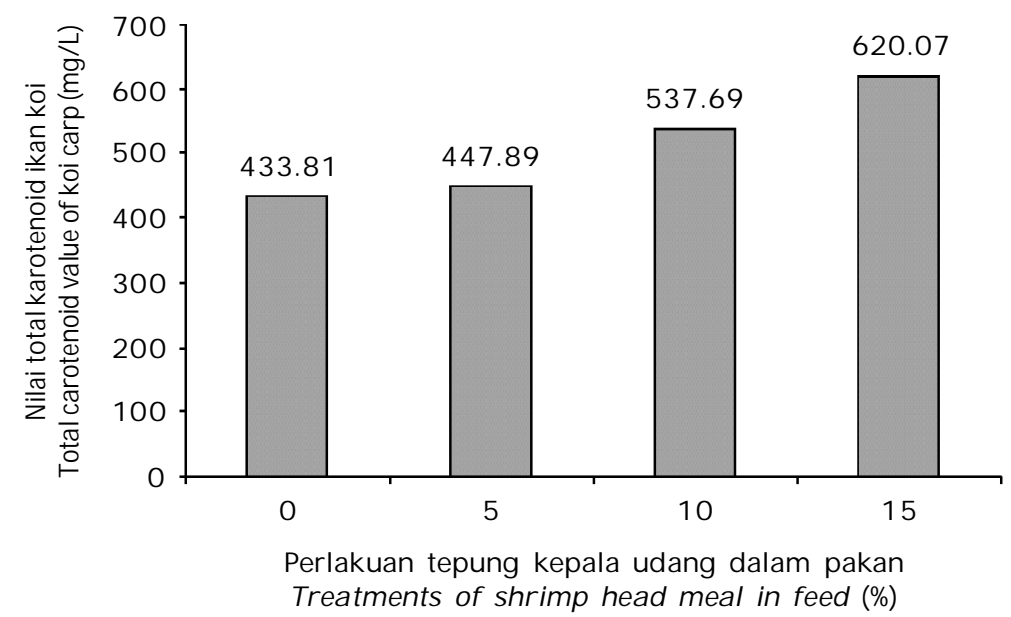

Gambar 4. Nilai total karotenoid ikan koi dalam spektrofotometer pada akhir penelitian

Figure 4. Total carotenoid value of koi carp in spectrophotometre on the last research period 
Tabel 3. Data kualitas air pada pemeliharaan ikan koi

Table 3. Data of water quality on the rearing of koi carp

\begin{tabular}{lccc}
\hline $\begin{array}{c}\text { Parameter } \\
\text { Parameters }\end{array}$ & $\begin{array}{c}\text { Satuan } \\
\text { Units }\end{array}$ & $\begin{array}{c}\text { Kisaran nilai } \\
\text { Range of values }\end{array}$ & $\begin{array}{c}\text { Kisaran kelayakan* } \\
\text { Range of properness }\end{array}$ \\
\hline Oksigen (Oxygen) & $(\mathrm{mg} / \mathrm{L})$ & $2.00-4.00$ & $>3.50$ \\
Suhu (Temperature) & $\left({ }^{\circ} \mathrm{C}\right)$ & $27.0-27.5$ & $25.0-30.0$ \\
$\mathrm{pH}$ & - & 7.00 & $6-8$ \\
$\mathrm{Kesadahan}$ (Hardness) & $(\mathrm{mg} / \mathrm{L})$ & $52.68-61.00$ & $<100$ \\
$\mathrm{NH}_{3}-\mathrm{N}$ & $(\mathrm{mg} / \mathrm{L})$ & $0.000-0.002$ & $<0.002$ \\
$\mathrm{NO}_{2}^{-}$ & $(\mathrm{mg} / \mathrm{L})$ & $0.002-0.003$ & $<0.005$ \\
Alkalinitas (Alcalinity) & $(\mathrm{mg} / \mathrm{L})$ & $22.66-33.98$ & $<100$ \\
\hline
\end{tabular}

* Boyd (1990); Mills \& Lamnert (2004)

Penggunaan tepung kepala udang yang digunakan dalam penelitian ini adalah sebagai sumber karotenoid (astaksantin dan cantaksanthin) alami yang diharapkan akan memudahkan proses penyerapan metabolismenya di dalam tubuh. Astaksantin memiliki fungsi biologis yang berhubungan dengan pertumbuhan, reproduksi, dan antioksidan pada salmon dan udang (Bell, 2000). Astaksantin murni maupun sintetik dapat ditambahkan dalam pakan ikan untuk meningkatkan warna ikan hias (Torrissen, 1988). Sedangkan canthaksantin ( $\beta$, $\beta$-karotena-4,4dione) memiliki kromatofora yang lebih panjang dan menyerap cahaya pada panjang gelombang yang lebih tinggi (Guillaume et al., 2001).

Berdasarkan hasil penelitian pada ikan koi diketahui bahwa pemberian tepung kepala udang dalam pakan dapat meningkatkan kualitas warna ikan. Peningkatan kualitas warna terukur dengan kuantifikasi visual menggunakan TCF untuk memudahkan penilaian warna. Selain itu pengukuran kualitas warna juga dilakukan dengan alat spektrofotometri dan telah menghasilkan perubahan warna yang cukup signifikan antar perlakuan pada ikan koi.

Dengan penambahan karoten dalam tubuh ikan maka dapat meningkatan penyerapan sel- sel pigmen sehingga kualitas warna ikan pun akan meningkat, dibandingkan dengan pemberian pakan tanpa karoten. Hal tersebut berlaku pada penelitian ini, di mana ikan koi yang diberikan pakan tanpa sumber karoten yang berasal dari tepung kepala udang, peningkatan warnanya lebih lambat dibandingkan yang menggunakan tepung kepala udang. Pemberian tepung kepala udang sebesar $10 \%$ menunjukkan performansi warna yang sama atau hampir sama baik secara kuantifikasi visual menggunakan TCF ataupun analisis nilai total karotenoid menggunakan spektrofotometer.

Kemampuan hidup ikan koi pada penelitian ini juga didukung oleh nilai kualitas lingkungan dalam hal ini kualitas fisika dan kimia air seperti pada Tabel 3. Data kualitas air pada Tabel 3 menunjukkan parameter fisika kimia yang masih berada dalam kisaran normal khususnya pada pemeliharaan ikan di dalam kolam.

\section{KESIMPULAN DAN SARAN}

Hasil penelitian menunjukkan bahwa peningkatan kualitas warna pada ikan koi optimal pada pemberian tepung kepala udang sebesar $10 \%$ dalam pakan. Tidak ada perbedaan yang signifikan pada pertumbuhan bobot (bobot mutlak, laju pertumbuhan spesifik tubuh), pertumbuhan panjang (panjang mutlak, laju pertumbuhan spesifik panjang) dan sintasan pada semua perlakuan persentase kepala udang dalam pakan pada benih ikan koi.

\section{DAFTAR ACUAN}

Anonim. 2002. (http:// www.o-fish.com/Spesies/ warna.php), 20 Agustus 2009, pk 11.13 WB.

Anonim. 2009. Pigmen Karotenoid. (http:// nakedfisher .blogspot.com), 19 Maret 2010, pk 15.00 WIB.

Bandyopadhyay, P., Swain, S.K., \& Mishra, S. 2005. Growth and dietary utilization in goldfish (Carassius auratus Linn.) fed diets formulated with various local agro- 
produces. Bioresource Technology, 96: 731- 740 .

Bell, J.G. 2000. Depletion of tocapherol and astaksantin in Atlantic Salmon affect autoxidative defence and fatty acid metabolism. Journal of Nutrition, 130(7): 1,800$1,808$.

Benjakul, S. \& Sopharodora, P. 1993. Chitosan production from carapace and shell of black tiger shrimp. Asean Food Journal, 8: 4.

Bjerkeng, B., Storebakken, T., \& Jensen, S.L. 1992. Pigmentation of Rainbow Trout From Start Feeding to Sexual Maturation. Aquaculture, 108: 333- 346.

Boyd, C.E. 1990. Water quality in ponds for aquaculture. Alabama Agricultural Experiment Station: Auburn University. Birmingham Publishing Co, $482 \mathrm{pp}$.

Damuningrum, A. 2002. Mempelajari karakteristik bakso ikan nila (Oreochromis niloticus) dengan penambahan bubuk flavor dari ekstrak kepala udang windu (Penaeus monodon). Skripsi. Bogor: Fakultas Perikanan dan Ilmu Kelautan, Institut Pertanian Bogor. Tidak dipublikasikan.

Desiana. 2000. Ekstraksi pigmen karotenoid dari limbah kulit udang windu (Penaeus monodon Fabricus) dengan bantuan enzim papain. Skripsi. Fakultas Perikanan dan Ilmu Kelautan IPB. Bogor. Tidak dipublikasikan.

Evans, D.H. 1993. The Physiologi of Fishes. CCR Press, London.

Goodwin, T.W. 1984. The Biochemistry of Carotenoids, $2^{\text {nd }}$ ed. Chapman $\&$ Hall, London, p. 64-96.

Guillaume, J., Kaushik, S., Bergot, P., \& Metailler, R. 2001. Nutrition and Feeding of Fish and Crustaceans. UK: Praxis Publishing, 408 pp.

Iwasaki, R. \& Murakoshi, M. 1992. Palm Oil Yields Carotene For World Markets. Inform, 3(2): 210- 217.

Johnson, E.A. 1991. Astaksantine from microbial source. Crit. Rev. in Biotechnology, 11(4): 297- 326.

Kalinowski C.T., Izquierdo, M.S., Schuchardt, D. , \& Robaina, L.E. 2007. Dietary supplementation time with shrimp shell meal on red porgy (Pagrus pagrus) skin colour and carotenoid concentration. Aquaculture, 272: 451- 457.

Karmas, E. 1982. Meat Poulltry and Seafood Technology. Recent Development, Dept of
Food Sci. Rutgers University. Park Ridge, New Jersey.

Latscha, T. 1990. Carotenoids their nature and significance in animal feeds. F HoffmanLa Roche Ltd. Swittzerland.

Latscha, T. 1991. Carotenoids In Aquatic Animal Nutrition. Dalam: D.M. Akiyama dan R.K.H. Tan (eds.). 1991. Proceedings of The Aquaculture Feed Processing and Nutrition Workshop. American Soybean Association, Singapore, p. 68- 79.

Lochmann, R.T. \& Phillips, H. 1994. Dietary protein requirement of juvenile golden shiners (Notemigonus crysoleucas) and goldfish (Carassius auratus) in aquaria. Aquaculture, 128: 277- 285.

Mills, D. \& Lamnert, D. 2004. The Aquarium Fish Handbook. Grange Books. United Kingdom. $256 \mathrm{pp}$.

Min Xue \& Cui, Y. 2001. Effect of several feeding stimulants on diet preference by juvenile gibel carp Carassius auratus gibelio, fed diets with or without partial replacement of fish meal by meat and bone meal. Aquaculture, 198: 281- 292.

Rosa Cejas, J., Almansa, E., Tejera, N., Jerez, S., Bolan, A., \&Lorenzo, A. 2003. Effect of dietary supplementation with shrimp on skin pigmentation and lipid composition of red porgy (Pagrus pagrus) alevins. Aquaculture, 218: 457- 469.

Sachindra, N.M., \&Mahendrakar, N.S. 2005. Process optimization for extraction of carotenoids from shrimp waste with vegetable oils. Bioresource Technology, 96: 1,1951,200 .

Sales, J., \& Janssens, G.P.J. 2003. Nutrient requirements of ornamental fish. Aquat. Living Resour, 16: 533- 540.

Sally, E. 1997. Pigmen Granula Transport in Cromatophores. Department of Biology, Bucknell University, Lewisburg.

Sánchez- Camargo, A.P., Almeida Meireles, M.Â., Fontoura Lopes, B.L., \& Antonio Cabral, F. 2011. Proximate composition and extraction of carotenoids and lipids from Brazilian red spotted shrimp waste (Farfantepenaeus paulensis). Journal of Food Engineering, 102: 87- 93.

Shahidi, F. \& Synowicki, I. 1992. Quality and Composional Characteristic of Newfaunland Shellfish Processing Discard in "advance in chitin and chitosan". Elsevier Applied Science. London. 
Soetomo, M. 1990. Teknik Budidaya Udang Windu. Sinar Baru, Bandung.

Storebakken, T. 1992. Pigmentation of rainbow trout. Aquaculture, 100: 209- 229.

Tonissen, O.J., Hardy, R.W., Shearer, K.D., Scott, T.M., \& Stone, F.E. 1990. Effects of dietary canthaxanthin level and lipid level on apparent digestibility coefficients for canthaxanthin in rainbow trout (Oncorhynchus mykiss). Aquaculture, 88: $35 \mathrm{I}-362$.

Torrissen, J. 1988. Pigmentation of Salmonoid Carotenoid Deposition and metabolism. Aquatic Sciences Vol I, Washington.
Vevers, G. 1982. The Colours of Animals. Edward Arnold (publisher), London.

Yandes, Z.R., Affandi, R., \& Mokoginta, I. 2003. Pengaruh pemberian sellulosa dalam pakan terhadap kondisi biologis ikan gurame (Osphronemus gouramy lac). J. Ikhtiologi Indonesia. 3(1): 27- 32.

Yanong, R.P.E. 1996. Reproductive Management of Freshwater Ornamental Fish. Seminars in Avian and Exotic Pet Medicine, 5(4)(October): p. 222- 235. 